\title{
Accessing local foods: H ouseholds using SNAP double bucks and financial incentives at a Midwestem farmers market
}

\author{
James R. Farmer, a* Angela Babb, b and Sara Minard c \\ Indiana University \\ Marcia Veldman ${ }^{\mathrm{d}}$ \\ City of Bloomington
}

Submitted February 21, 2018 / Revised June 11, July 13, September 24, and O ctober 15, 2018 /

Accepted October 16, 2018 / Published online February 13, 2019

Citation: Farmer, J. R., Babb, A., Minard, S., \& Veldman, M. (2019). Accessing local foods: SNAP-D ouble

Bucks households and financial incentives at a midwestern farmers market. Journal of A griculture, Food Systems, and C ommunity D evelopment, 8(4), 153-178. https:/ / doi.org/ 10.5304/ jafscd.2019.084.005

Copyright (c) 2019 by the Authors. Published by the Lyson Center for Civic Agriculture and Food Systems. Open access under CC-BY license.

\begin{abstract}
Farmers markets have flourished in recent decades as alternative distribution outlets for small-scale, organic producers. However, one persistent challenge for farmers markets is attracting a diverse range of patrons across the wide socio-economic spectrum. This issue is even more critical when focused on individuals with a limited budget for

a* Corresponding author: James R. Farmer, Ph.D ., Associate Professor, School of Public and Environmental Affairs, Indiana University; $1025 \mathrm{E}$. 7th Street, SPH 133; Bloomington, IN 47405 USA; +1-812-856-0969; jafarmer@ indiana.edu

${ }^{b}$ Angela Babb, M.A., Research Associate, D epartment of Geography, Indiana University, ababb@iu.edu

c Sara Minard, M.S., Visiting Lecturer, D epartment of G eography, Indiana University, sminard@indiana.edu

d Marcia Veldman, Coordinator, Bloomington Community Farmers Market, Bloomington Parks and Recreation, City of Bloomington, veldmanm@bloomington.in.gov
\end{abstract}

food expenditures. Thus, we surveyed SNAP and non-SNAP users who attend a Midwestern farmers market in order to investigate motivations for attendance, local food values, and the role that financial incentives play in affecting attendance. Additionally, we compared our findings with our previous research on households who receive SNAP and do not attend the farmers market. O ur results underscore that the SNAP users at the market have much in common with their nonSNAP market-going counterparts. There are also several critical differences between market-going SNAP users and the non-going SNAP users. In conclusion, while our results show financial incen-

\section{Funding Disclosure}

This project was supported by the Indiana Clinical and Translational Sciences Institute, funded in part by grant \#UL1TR001108 from the National Institutes of Health, National Center for Advancing Translational Sciences, Clinical and Translational Sciences A ward. 
tives work to reduce the reproduction of economic privilege at the farmers market, additional initiatives are required to address other food access barriers and to promote food justice in this important and expanding space.

\section{Keywords}

Farmers Markets, Local Food, SNAP, D ouble Market Bucks, Financial Incentives, Parks Department

\section{Introduction}

The number of farmers markets nearly doubled between 2008-2014, from 4,685 to 8,497 (USDA AMS, 2015). These direct-to-consumer food markets have long been touted as a method to increase community food security (Kantor, 2001); while consumers have better access to fresh, healthy, and organic foods, producers gain economic and social support from their local communities.

Scholars point to a number of benefits, both individual and communal, derived from thriving farmers markets. For example, farmers capture more revenue in direct-selling schemes (La Trobe, 2001; Mann et al., 2018), local and regional food systems can enhance food security (Allen, 1999), markets allow consumers to signal a desire for sustainable consumption options (Seyfang, 2006), shoppers attend markets for both food purchasing and entertainment (Farmer, Chancellor, Gooding, Shubowitz, \& Bryant, 2011), health benefits can accrue from increased fresh fruit and vegetable consumption (Herman, Harrison, Afifi, \& Jenks, 2008), and the environment benefits from increased caloric reliance on fruits and vegetables (Godfray et al., 2010) that supplant animal-based products; these are all touted benefits.

Community development is also seen as an indirect benefit from a successful farmers market, particularly those markets that cater to a diverse swatch of a community's population. As noted by Mann et al. (2018) and others, the acceptance of Supplemental Nutrition Assistance Program (SNAP) benefits within the local food sector is perceived as a way to enhance community development via economic development benefits (Bell, Mora, Hagan, Rubin \& Karpyn, 2013). A second and related example includes the spillover effects of consumer spending. This is the idea that certain consumers who attend farmers markets are the same individuals who will shop at nearby establishments as they venture to and from the market (Cummings, Kora, \& Murray, 1999). This has been used as evidence to support positioning markets in areas that need visitor bolstering. O ther scholars have found that markets are a means for the production of social and community capital as patrons are able to visit with friends, acquaintances, and community leaders (O berholtzer \& Grow, 2003). Finally, market location can provide community benefits in locales with few other food outlets, such as the case in Flint, Michigan (Sadler, 2016).

Unfortunately, farmers markets can also have negative consequences: they have frequently been charged with serving primarily affluent and white users while neglecting the needs of those living in poverty and minority populations (Farmer, Chancellor, Robinson, West, \& Weddell, 2014; Markowitz, 2010; Hinrichs \& Kremer, 2002). Critics also caution against overly optimistic interpretations of the local food effects that farmers markets can have on communities (Hinrichs, 2000; Hinrichs \& Kremer, 2002). Especially with regard to low-income populations, local foods can be more expensive than conventionally produced foods. The privilege of eating local (Farmer et al., 2014) has meant that farmers markets often remain inaccessible to many low-income households. The price of foods at farmers markets are complicated and often highly debated as comparing prices in and outside of farmers markets is difficult. Several researchers have found farmers market prices to be higher than the price of similar items at surrounding supermarkets (Garrett, 2014; Lucan, Maroko, Sanon, Frias, \& Schechter, 2015). However, other reports point to the prices being quite parallel (Vermont Agency of Agriculture, Food and Markets, 2016; McD aniel, 2014). The accuracy of such arguments are likely quite contextual to the farmers markets in question. Other barriers include the geographic location of the markets and market open times. Farmers markets are most commonly positioned in affluent, white areas (Singleton, Sen, \& Affuso, 2015), and potential low-income participants experience a range of access barriers, includ- 
ing lack of time and inadequate transportation (Walker, Keane, \& Burke, 2010). Local foods are also limited by season and are more labor intensive to locate and prepare; thus, they may be perceived as an impractical food solution for many potential consumers (Leone et al., 2012). In addition to physical and economic barriers, several sociocultural factors may deter the patronage of some populations, including SNAP recipients (G uthman, 2008). Characterized by the actual bodies present at the market (Slocum, 2008) and the cultural and environmental values of market founders and managers (Alkon, 2012), farmers markets can be unwelcoming or inadequate to subpopulations within a community (D eLind, 2006).

In an attempt to remedy economic issues, farmers markets across the U.S. have engaged in initiatives to increase equitable access to local foods among households with low income, particularly among participants of the Supplemental Nutrition Assistance Program (SNAP), the Senior Farmers Market Nutrition Program (SFMNP), and the Special Supplemental Nutrition Program for Women, Infants, and Children (WIC). These are fairly recent developments, beginning circa 2005 (Winch, 2008); hence, little research has been done to assess the efficacy of these financial incentives and their impact on the affordability and accessibility of farmers markets to households with low income. While recent scholarship has highlighted the benefits of economic incentive programs to specific segments of farmers markets (O berholtzer, Dimitri, \& Schumacher, 2012), few have assessed these initiatives within a framework that also considers the embedded socio-cultural values of participants and demographic privilege. Thus, the overarching question of this study is: to what ex tent does the implementation of financial incentives at farmers markets work to mitigate food insearity by reduang barriers between low-income households and local foods distributed at farmers markets?

Consumers participating in local food networks, such as farmers markets, cite several motivations, barriers, and disincentives for participation. Recreation and leisure were the most frequently reported reasons for participation amongst farmers market shoppers in Indiana, USA (Farmer et al., 2011). These shoppers also reported that they valued supporting local farmers and were motivated by the quality, freshness, and variety of foods available at farmers markets, as well as the ability to know where and how the food was produced. Major constraints to participation, as reported by these shoppers, were the monetary cost of food and the lack of convenience, relative to surrounding supermarkets. D uring 2012, lowincome households in Bloomington, Indiana, claimed essentially the same motivations--quality, freshness, and variety of foods-- similar barriers to participation-- cost and inconvenience--as well as a general lack of information about the farmers market (Babb, 2013).

A study by Farmer et al. (2014) systematically compared the food values of farmers market participants with that of nonparticipants. The researchers looked at 12 categories of food values collected from the literature: environment, nutrition, local farmers, fewer chemicals, local economy, fresh food, hormone free, organic, whole foods, humane, seasonal, local (within 100 miles [161 $\mathrm{km}]$ ), and costs of food. Farmers market participants ranked all food-value motivations higher overall than non-farmers market participants. Environmental and nutritional motivations ranked the highest among participants. These two motivations ranked fifth and twelfth, respectively, among nonparticipants. This illustrates a connection between food values and participation in local food networks.

Also illustrated are the complex social barriers that may exclude many from participating, including gender, education, income, social connectedness, and ethnicity. Wolf, Spittler, and Ahem (2005) found that farmers market goers were generally younger, were more likely to be female, were more likely to be married, had a higher educational attainment status, and had a higher income level compared to the general population. Zepeda (2009) found that those not going to farmers markets were more interested in the convenience of purchasing food, were single, and in a single-parent household; Zepeda (2009) found no difference in income between market shoppers and nonattendees. Yet, others have found that location and facilities, the market atmosphere, and time constraints pivotally affect participation in farmers 
markets, acting as either barriers or disincentives (Colasanti, Conner, \& Smalley, 2010). Specifically, Calasanti et al. (2010) found that female Latinas were most likely to find the aforementioned variables to be critical components in making the decision to shop or not to shop at a farmers market.

The SNAP has increased food security for millions across the U.S. while alleviating the severity of poverty among low-income households, particularly those with children (Tiehen, Jolliffe, \& Gunderson, 2012). Specifically, the acceptance of SNAP benefits at farmers markets has been shown to reduce nutritional disparities within communities (Jones \& Bhatia, 2011), but physical barriers have deterred SNAP use at these outlets. Food stamp redemption at farmers markets decreased drastically during the 1990s as states transitioned to electronic benefits transfer (EBT) systems (Kantor, 2001). EBT cards, which function like debit cards, have posed a problem for farmers markets that do not have a telephone line, internet, or electricity to process EBT transactions (Markowitz, 2010). To promote equitable access to farmers markets, the 2008 U.S. Farm Bill allocated 10.0\% of funds in the Farmers Market Promotion Program to helping farmers markets acquire the means to accept EBT cards. In San Francisco, the acceptance of EBT was mandated for all farmers markets in 2006. Since then, SNAP receipts have increased on average $57.0 \%$ each year, with a $91.0 \%$ increase between 2009 and 2010 (Jones \& Bhatia, 2011). Still, even when SNAP transactions are enabled at farmers markets, the cost of foods remains another barrier to participation.

While a consensus has not yet been reached (Mann et al., 2018), some researchers have found the price of foods at farmers markets to be higher than the price of similar items at surrounding supermarkets (G arrett, 2014; Lucan et al., 2015). Thus, in 2005, private and non-governmental organizations began offering financial incentives that double the value of SNAP, WIC, and SFMNP coupons at farmers markets (Winch, 2008). Financial incentives at farmers markets in New York City, Boston, and San Diego have impacted the vegetable consumption of some mothers (Dimitri, 2015). Hicks and Lambert-Pennington (2014) also found similar patterns with SNAP being accepted at markets, thus driving engagement amongst those with low socio-economic status. Indeed, participants with limited access to fresh fruit and vegetables in their communities and whose consumption averages less than two servings of vegetables each day were more likely to increase vegetable consumption using the incentives at the farmers market. This research suggests that financial incentives may help low-income consumers who already attend or are interested in the market; but, further research is needed to understand how to incentivize the most vulnerable consumers-- those with the most limited access to fresh fruits and vegetables and households using emergency food outlets, such as food banks and pantries.

Multiple studies have purported positive outcomes from matched farmers market incentive programs. Lindsay et al. (2013) found that participants in matched programs reported nearly a 16fold increase in eating healthy or very healthy when compared to their eating behavior prior to being part of an incentive match program. Participants were almost unanimous (93.0\%) in stating that the matched program was vital to their decision to shop at a farmers market. Studies that looked at similar market buck programs found that participants reported eating more fruits and vegetables due to such programs (Bowling, Moretti, Ringelheim, Tran, Davison, 2016; Payne et al., 2013).

In this paper, we perform an exploratory comparison of SNAP and non-SNAP users at the Bloomington Community Farmers' Market (BCFM), as well as a comparison between SNAP market users and SNAP users not attending the market. We did this comparison to assess the efficacy and importance of financial incentives for SNAP participants at the BCFM. In doing so, we ask the following research questions:

1. What are the similarities and differences between SNAP and non-SNAP households at the farmers market?

2. What are the similarities and differences between SNAP users attending the BCFM and SNAP users who do not?

3. How important are financial incentives, particularly the double market bucks program, to SNAP households attending the farmers 
market and for bringing new SNAP households to the farmers market?

We understand that farmers markets are not the panacea for food insecurity; rather, they are just one outlet for promoting both household and regional food security. Because farmers markets are not necessarily culturally appropriate for all communities, we expect to find that individuals with similar motivations and values attend farmers markets. Therefore, we hypothesize that, while household income levels and educational attainment will differ between SNAP and non-SNAP users, few, if any, other differences (food values, value for local food and farmers, market behaviors) will exist between the two groups. Additionally, we hypothesize that the double market bucks program will be an important consequence to SNAP users already attending the BCFM; however, we hypothesize that this financial incentive is not vital to bringing new, diverse populations to the market, particularly those who have no prior interest in shopping at the BCFM and those who face more than just economic barriers to participation.

\section{Methods}

This study is part of a larger community-based participatory research (CBPR) project that has sought to improve food security in and around Bloomington, IN, through the use of local foods. We chose the CBPR approach because it combines the knowledge, skills, and assets of local people and organizations and those of professional scientists to develop practical and applied solutions to pressing issues (Fortmann, 2008) that work toward a socially just end (Strand, Marullo, Cutforth, Stoecker, \& D onohue, 2003). Consequently, we had three community partners that collaborated with the professional researchers on the overall project. These included Monroe County United Ministries, the Local Growers G uild, and Bloomington Parks and Recreation.

The current study is the final phase of a four- part study. ${ }^{1}$ In this paper, we discuss Phase 4 , with highlights from Phase 1 (Farmer, Minard, \& Edens, 2016). The current manuscript predominantly includes results from a questionnaire used to survey SNAP and non-SNAP users attending the BCFM. Phase 1 was a door-to-door survey in neighborhoods that are characterized as low and mixed income in the City of Bloomington. We use overlapping questions and corresponding data from the two phases as part of our analysis.

\section{Study Site}

This survey was administered at the Saturday BCFM in Bloomington, Indiana. Bloomington is a town of approximately 83,300 residents (City of Bloomington, 2016) and is located in south-central Indiana approximately 60 miles (96 kilometers) from the state capital, Indianapolis. Bloomington is located in Monroe County, population 137,974. The population of Bloomington has a median age of 23.4 years and is $83.0 \%$ White, $4.6 \%$ Black or African American, 8.0\% Asian, and 3.5\% Hispanic (of any race). Indiana University's flagship campus is located in Bloomington, which does have a significant effect on the city's economy, demographics, and culture.

The BCFM was established in 1975 and is the state's largest farmers market by number of vendors and visitors. Counts for the attendance at the Saturday farmers market during the summer have often exceeded 10,000 visitors in recent years. The City of Bloomington's Parks and Recreation D epartment manages the market, which is located in the heart of the city adjacent to the Shower's Building (i.e., the headquarters for the city government). Positioned a few steps from the city's main urban trail corridor, the market draws patrons on bike, foot, bus, or arriving in private cars. The 75+ vendors sell products beginning in early A pril through late November. Common products include Indiana classics such as sweet corn, tomatoes, squash, and green beans, while also tapping into international cuisine items such as kohlrabi,

\footnotetext{
${ }^{1}$ Phase 1 included door-to-door structured interviews of residents in neighborhoods characterized as low and mixed income. Phase 2 entailed a mail survey to farmers servicing the local community. Phase 3 included informal, in-depth interviews with key informants working for social service and food and/ or agricultural agencies. Phase 4 included a questionnaire used to survey SNAP and nonSNAP users at the Bloomington Community Farmers' Market.
} 
Asian greens, "pet" food dairy products (cow and goat products being legally sold for pet consumption only; however, they are often consumed by humans), honey, hot peppers, and a variety of ready-made hot items. Beyond patrons and farmers, the market is home to musicians busking for dollars, a few clowns on occasion, and folks attending for a morning coffee, scone, and visit with friends.

The D ouble Market Bucks Program (D MBP) began in the summer of 2013 and is funded by private donations. O nce per week, SNAP participants can trade up to US\$18 in SNAP benefits for double the value (up to US\$36) in Market Bucks. Market Bucks are issued in US\$3 increments and are used like cash by market goers, except vendors cannot give change for Market Bucks. At the end of market hours, vendors redeem the Market Bucks they received for cash. After one year of the DMBP, the receipt of Market Bucks increased fivefold and EBT transactions more than doubled at the BCFM (Wooten, 2013). Market Bucks receipts increased another 17.0\% in 2014 before decreasing by $4.0 \%$ during 2015 (Lay, 2015).

As of 2012, the majority of households with low incomes surveyed in Bloomington were interested in shopping at the community farmers market but were experiencing a range of economic, physical, and cultural barriers; at that time, food pantries were the main connection between lowincome households and local foods in Bloomington (Babb, 2013). The D MBP was implemented at the BCFM in 2013, and during that season, SNAP receipts more than doubled (Wooten, 2013), indicating that this financial incentive has been successful in some regard. Overall, these financial incentives are relatively new, and few studies have assessed the utility of such initiatives implemented at farmers markets. Moreover, the cost of foods at farmers markets is just one potential barrier to participation. In this paper, we assess the utility of the DMBP from the perception of SNAP participants. In an exploratory fashion, we compare the demographics, values, motivations, and behaviors of SNAP participants at the farmers market with those of non-SNAP participants. We consider the aforementioned variables as explanatory and question whether the D MBP works to negate such variables at the BCFM. We do this by comparing market SNAP users to market non-SNAP users; we also compare market going SNAP users to our previous research results conducted in neighborhoods dominated by low-income households who use SNAP benefits.

$D$ ata Collection

The 28-item survey instrument was developed in partnership with representatives from our collaborating agencies, BCFM, the Local G rowers G uild, and Monroe County United Ministries. BCFM was particularly invested in this, as the survey also served to query shoppers' perspectives on current offerings. A prior market survey from 2010 helped inform the creation of the current instrument, which was designed to survey both SNAP and non-SNAP market shoppers and included a fourquestion section that pertained only to SNAP shoppers. The 28 items were a mix of multiplechoice, ranking, and fill-in-the-blank questions covering three categories of inquiry: farmers market experience, food values and household behavior, and demographics (see Appendix B). The instrument was piloted three times to clarify the wording and to make the questions more precise. SNAP and non-SNAP data collection mainly took place over four weekends in June and July of 2015, with an additional early August weekend used for SNAP data collection.

We used a convenience sampling approach with incentives. Non-SNAP users were offered a US\$5 market gift certificate as an incentive to participate in the 10-minute survey. SNAP users redeeming SNAP dollars for Market Bucks were asked if they would be willing to participate in BCFM research and were offered a US\$10 market gift certificate as an incentive. O ur research team approached 278 non-SNAP users, of which 172 filled out a market survey. Of the 103 SNAP users approached, 89 filled out the survey. In 2014, the BCFM tallied 247 unique SNAP users attending the market.

Statistical A nalysis

D escriptive results are presented in Appendix A, along with an analysis of variance (ANOVA) and chi-square comparisons between SNAP and non- 
SNAP users. These analyses compare scores between the groups, testing for differences. ANOVAs were used to test for differences between the groups using continuous data, such as Likert scales, age, etc. Chi-square was used to compare categorical data, such as gender, educational attainment, etc. Between-group comparisons are included in Tables 1, 2, and 3, which encompass prompts from Q uestions 3 (commonly purchased products), 9 (motives for attending the farmers market), 10 (benefits from attending the farmers market), and 17 (values for local foods). We then used principal-components analysis (PCA) for questions 9,10 , and 17 in order to evaluate the relationship between prompts and across answers (Tables 2 and 3). The PCA allowed us to determine if relationships exist between various prompts and to combine prompt scores and develop composite means for later use in the regression analyses (Table 4). PCA statistics were developed and presented for questions 9,10 , and 17 , and further consideration of each component was made using Cronbach's alpha scores for each component. Cronbach's alpha scores were used to determine the strength of a relationship between items. Components with a Cronbach's alpha level above 0.700 were used in further analysis, which is the common acceptable threshold (Field, 2013). We also delved specifically into SNAP user data in order to discem the importance of Market Bucks to their participation at the market; we also graphed beginning attendance at the BCFM, comparing SNAP vs. non-SNAP consumers.

Finally, we used regression analysis to understand what variables best predicted if someone was or was not a SNAP user. Fifteen different independent variables (see Table 4) were included in the analysis to determine the strongest predictors for distinguishing between SNAP $(=1)$ and non-SNAP (=0) users. Regression analysis provides a basis for understanding how independent variables relate to a dependent variable (SNAP vs. non-SNAP in the current case).

\section{Results}

We present our results in three sections, starting with a description of the response rate and demographic results. Next, we review market behaviors, motivations for attending the market and for engaging in local food systems, and the importance of Market Bucks for SNAP users. The final section presents a regression model used to better understand the differences in SNAP and non-SNAP market goers.

Survey Response 0 verview and BCFM Participant Profile O ur overall response rate was $68.4 \%$, with SNAP users responding at $86.3 \%$ and non-SNAP users responding at $61.8 \%$. Overall, participants were mostly female, White, about 42.5 years of age, had at least one child in the household, and attended religious services at least once a year (Appendix A). Market goers generally attended the BCFM 2.54 times each month during the season, had been attending for 8.5 years, and spent over US\$23 per visit. SNAP users at the market were more often female, younger, and with more children in the household; not surprisingly, they also had lower educational attainment, lower household incomes, and were more likely to be people of color (Appendix A). The SNAP users we surveyed at the farmers market were more likely to be female, to have attained a higher educational level, to have a higher income, to have less difficulty in getting to the grocery store, and to participate less frequently in religious services compared to the SNAP users from our Phase 1 study.

\section{Mark et Behaviors}

Little difference was found to exist in the market behaviors between the two populations surveyed. SNAP users attended the market 2.55 times per month, while non-SNAP users attended the market 2.53 times per month. Non-SNAP users had been attending the market on average 9.10 years, with SNAP users attending for the past 7.28 years. This was not statistically different. Similarly, the two populations spend fairly equitable amounts of outof-pocket money per week, not including SNAP benefits (SNAP $=$ US $\$ 20.43$; non-SNAP= US\$24.80; $p=.051$ ). Though duly noted, a p-value of .051 is marginally significant and on the cusp of being statistically significant beyond random chance). As a result of shopping at the market, no difference was found in the amount of fresh fruits 
and vegetables

purchased out of

pocket between

the two groups. How-

ever, a statistical differ-

ence was found in the

variety of fruits and

vegetables consumed.

SNAP users indicated

that attending the

market increased the

variety of their fruit

and vegetable con-

sumption more so than

the non-SNAP users.

SNAP users also noted that shopping at the farmers market increased the amount of fresh fruits and vegetables that they consume (mean of 1.93 out of $5.00 ; 1=$ increased greatly, $2=$ increased some, $3=$ stayed the same, $4=$ decreased some, $5=$ decreased greatly). Participants were asked to report the foods they most commonly purchased while shopping at the farmers market. Food groups included fruits, vegetables, breads, honey, meat, cheese, other dairy, and eggs.

SNAP users reported buying all of these items, except breads and vegetables, more often than non-SNAP users (Table 1). Both groups used similar transportation methods for getting to market, with personal automobile transportation ranking highest followed by walking (although to a much lesser extent). Finally, we asked study participants how difficult it was getting to the grocery store. We had them rate the difficulty on a scale of 1 to 4 (1=very difficult, $2=$ difficult, $3=$ =easy; $4=$ very easy). Difficulty in getting to the grocery store is used as a proxy for transportation as a barrier (Farmer et al., 2017). SNAP users responded with an average score of 3.11 (easy), which was statistically different from the average response of non-SNAP users: 3.47 (even easier).

MotiveV alues

We also asked all study participants to rate their level of agreement regarding common motivations and values, as defined by the literature, pertaining to why one might attend a farmers market (see Table 2). The Likert-style scale was a 1-to-5, 1= strongly disagree to $5=$ strongly agree. The ratings of two motive-values were significantly different between the two groups: the desire to learn about farming and gardening and the desire to purchase food inex pensively. SNAP users scored these items significantly higher (at the $\mathrm{p}<.05$ and $\mathrm{p}<.001$ levels, respectively).

We conducted a PCA on the results of the motive-values to evaluate the relationship between the 12 items in this scale, as well as to be able to combine related variables into composite mean scores for later use in the regression analyses (which involved predicting what variables best identify the SNAP users vs. the non-SNAP users). The results detected the presence of one component with an Eigenvalue greater than one. The PCA met statistical rules and assumptions. The component is named based on the items grouping together at 400 or greater, as are the proceeding components discussed further on. Component 1 had a Cronbach's alpha score of .886 and explained $49.7 \%$ of the variance. This component included all items on the scale and was entitled M arket M otivations.

Using a similar approach, we evaluated the motive-values for why individuals partake in local food systems. This battery of questions included 13 items and also used a 1-5 Likert-style scale of "strongly disagree" to "strongly agree" (Table 3). Five items returned significantly different results between SNAP and non-SNAP users, with SNAP users assigning higher scores--I give preferenœ to foods that are grown with few chemical applications $(\mathrm{p}<.05)$, The 
Journal of Agriculture, Food Systems, and Community Development

ISSN: 2152-0801 online

https:/ / www.foodsystemsjournal.org

Table 2. Agreement with Common Motivations for Attending a Farmers Market: Overall and Group Mean Scores as Well as PCA Results from Q9 of the Survey ( $1=$ strongly disagree to $5=$ strongly agree)

\begin{tabular}{|c|c|c|c|c|}
\hline I go to the FM because I want... & Overall & SNAP & Non-SNAP & $\begin{array}{c}\text { Component } 1 \\
\text { ("Market } \\
\text { Motivations") }\end{array}$ \\
\hline Fresh food & 4.66 & 4.62 & 4.68 & .713 \\
\hline Food with higher nutritional value & 4.35 & 4.54 & 4.25 & .734 \\
\hline Food with fewer synthetic chemicals & 4.48 & 4.58 & 4.42 & .809 \\
\hline More variety & 4.00 & 4.05 & 3.97 & .677 \\
\hline Easier access to fresh food & 4.15 & 4.24 & 4.11 & .641 \\
\hline To purchase food inexpensively*** & 3.29 & 3.84 & 2.97 & .417 \\
\hline To learn about farming and gardening* & 3.25 & 3.56 & 3.07 & .498 \\
\hline Recreation opportunities & 3.65 & 3.80 & 3.57 & .486 \\
\hline To consume foods grown sustainably & 4.29 & 4.34 & 4.26 & .793 \\
\hline To support sustainable farming practices & 4.46 & 4.47 & 4.45 & .823 \\
\hline To support a local food system & 4.60 & 4.63 & 4.59 & .852 \\
\hline To support local farmers & 4.65 & 4.64 & 4.65 & .838 \\
\hline Overall & & 3.5 & 3.2 & \\
\hline
\end{tabular}

$* p<.05 ; * * * p<.001$

Table 3. Local Food Motive-Values from Survey Question 17 ( 1 =strongly disagree through $5=$ strongly agree)

\begin{tabular}{|c|c|c|c|c|c|c|}
\hline & Overall & SNAP & Non-SNAP & Comp. 1 & Comp. 2 & Comp. 3 \\
\hline $\begin{array}{l}\text { Purchasing organically grown food is very } \\
\text { important to me. }\end{array}$ & 4.27 & 4.40 & 4.20 & .868 & .174 & .032 \\
\hline $\begin{array}{l}\text { I give preference to foods that are grown with few } \\
\text { chemical applications.* }\end{array}$ & 4.46 & 4.60 & 4.38 & .853 & .220 & .113 \\
\hline $\begin{array}{l}\text { I give preference to foods that were picked just a } \\
\text { few days before my purchase. }\end{array}$ & 4.34 & 4.47 & 4.28 & .580 & .437 & -.195 \\
\hline $\begin{array}{l}\text { The nutritional value of a food is an important } \\
\text { part of my purchasing decisions.** }\end{array}$ & 4.43 & 4.61 & 4.33 & .725 & .314 & .049 \\
\hline $\begin{array}{l}\text { I give preference to animal products that have } \\
\text { been derived in a humane manner. }\end{array}$ & 4.03 & 4.20 & 3.94 & .221 & .095 & .805 \\
\hline $\begin{array}{l}\text { I give preference to animal products that are free } \\
\text { from growth hormones. }\end{array}$ & 4.44 & 4.43 & 4.45 & .629 & .469 & .469 \\
\hline $\begin{array}{l}\text { The expense of fresh local produce deters me } \\
\text { from purchasing it as often as I would like.* }\end{array}$ & 3.55 & 3.78 & 3.42 & -.049 & .092 & .548 \\
\hline $\begin{array}{l}\text { I generally purchase whole foods, rather than } \\
\text { processed foods. }\end{array}$ & 4.08 & 4.16 & 4.04 & .594 & .278 & .161 \\
\hline $\begin{array}{l}\text { I give preference to purchasing foods that come } \\
\text { from within } 100 \text { miles of my location. }\end{array}$ & 4.13 & 4.23 & 4.08 & .351 & .687 & -.011 \\
\hline $\begin{array}{l}\text { I give preference to eating foods that are in } \\
\text { season. For example, tomatoes in July-October. }\end{array}$ & 4.23 & 4.17 & 4.26 & .141 & .724 & .150 \\
\hline $\begin{array}{l}\text { I give preference to food purchase decisions that } \\
\text { support the local economy.* }\end{array}$ & 4.48 & 4.63 & 4.40 & .221 & .844 & .090 \\
\hline $\begin{array}{l}\text { I give preference to food purchase decisions that } \\
\text { support local farmers. }\end{array}$ & 4.55 & 4.60 & 4.52 & .306 & .802 & .116 \\
\hline $\begin{array}{l}\text { I believe consuming food produced locally is } \\
\text { better for the environment.* }\end{array}$ & 4.56 & 4.68 & 4.50 & .281 & .696 & .279 \\
\hline
\end{tabular}

$* \mathrm{p}<.05 ; * * \mathrm{p}<.01 ; * * * \mathrm{p}<.001$ 
nutritional value is an important part of my purchasing decisions ( $p<.01)$, The ex pense of fresh, local produce deters me from purchasing it as often as I would like $(\mathrm{p}<.05)$, I give preference to food purchase decisions that support the local economy $(\mathrm{p}<.05)$, and I believe consuming food produced locally is better for the environment $(p<.05)$. To test the statistical relationship between these results and to build composite variables for use in logistic regression, we performed a PCA on the 13 items in the battery. The results detected the presence of two useable components. The PCA again met statistical rules and assumptions. Component 1 had a Cronbach's alpha score of .855 and explained $44.6 \%$ of the variance. Component 1 included six items that focused on the preference of organic and/ or chemical-free foods, fresh foods, nutritional foods, hormone-free foods, and whole foods. We entitled Component 1 as Pure Food. Component 2 had a Cronbach's alpha score of .860, an Eigenvalue of 1.305, and explained $10.0 \%$ of the variance. This component comprised items concerning fresh, hormone-free, locally produced, seasonal, and environmentally sound foods, as well as foods supporting local farmers and the local economy. We entitled Component 2 as $\mathrm{L}$ ocally $\mathrm{G}$ ood Food.

U tility of the D ouble M ark et Buck s Program SNAP participants use Market Bucks on average 2.8 times a month and find them to be very important in one's decision to spend SNAP benefits at the Saturday BCFM (1.14 on a 1-4 scale with $1=$ very important and $4=$ not important). Surprisingly, 63 of 88 SNAP participants indicate that they would continue to shop at the BCFM if SNAP benefits were not accepted. SNAP users and non-SNAP users followed a parallel trajectory in participating in the farmers market, with no statistical difference detected on either groups' rate of increased attendance over time. A statistical difference was not found. We also asked participants "How did you learn about the double market bucks program?" Nearly $42 \%$ of SNAP users learned about the program while in attendance at the farmers market; $17.2 \%$ learned about the program through their social network and another $17.2 \%$ through a social service agency.

Another battery of questions sought information as to the importance of the various benefits of attending the market (Table 4). We asked participants to indicate their level of agreement on the importance of eight different benefits gained from market attendance. The acquisition of fresh food ranked highest, followed by safe food, and knowing how the food was grown. When testing for differences between SNAP users and non-SNAP users, we found no statistical differences. In addition, we conducted a PCA to measure the relationship between the eight items and to develop composite variables for later use in the regression analysis. The results detected the presence of one component with an Eigenvalue greater than one. Again, this PCA met the statistical rules and assumptions warranting the combination of these variables into a single composite variable. Component 1 had a Cronbach's alpha score of .833 and explained $52.3 \%$ of the variance. We named this component mark et benefits (Table 4).
Table 4. Benefits of Attending the Farmers Market ( $1=$ strongly disagree to $5=$ strongly agree)

\begin{tabular}{lcccc}
\hline & & & & $\begin{array}{c}\text { Comp. 1a } \\
\text { "Market } \\
\text { Benefits" }\end{array}$ \\
\hline Nutritional food & Overall & SNAP & Non-SNAP & .806 \\
Sense of belonging & 4.51 & 4.64 & 4.45 & .674 \\
Fresh food & 4.13 & 4.18 & 4.11 & .762 \\
Convenience & 4.62 & 4.69 & 4.58 & .601 \\
Opportunity for recreation & 3.83 & 3.92 & 3.77 & .673 \\
Social interaction with friends & 3.92 & 3.95 & 3.90 & .708 \\
Knowing how my food was grown & 4.04 & 3.94 & 4.09 & .743 \\
Safe food & 4.23 & 4.37 & 4.15 & .798 \\
\hline
\end{tabular}

$* p<.05 ; * * p<.01 ; * * * p<.001$

a KMO: .882, Sig: .000, Chi-S: 932.285 , CrA: .854, \% of var: 52.364, Eig: 4.138 varimax 
Finally, we conducted a binary logistic regression analysis in order to further explore the differences between SNAP and non-SNAP users at the farmers market (Table 4). Model 1 included 15 independent variables detailed in Table 5 . We regressed the model on $1=$ SNAP user and $0=$ nonSNAP user. The model fit the data well, was significant at the .015 level, and met the parameters needed to justify interpretation. Four variables were significant, including money spent at the market (outside of SNAP benefits), the mark et motivations composite variable from Table 2 , the number of children in the household, and the ease of getting to the grocery store. As scores changed in these four variables, the likelihood of being a

Table 5. Summary Statistics of the Binary Logistic Regression Model to Predict SNAP User Status Among Farmers Market Goers

\begin{tabular}{|c|c|}
\hline \multicolumn{2}{|l|}{ Model 1 (Step 4) } \\
\hline Model Sign & .015 \\
\hline Hosemer Lemeshow & .369 \\
\hline Chi-Square & 35.916 \\
\hline -2 Log Likelihood & 228.104 \\
\hline Nagelkerke & .223 \\
\hline Percentage Accuracy & $70.9 \%(87.8 \% \mathrm{FM} ; 40.3 \%$ SNAP) \\
\hline Variables & B (S.E.; $\operatorname{Exp}(B)$ \\
\hline Money spent at the farmers market & $-.029(.012 ; .972)^{*}$ \\
\hline Q9 Overall Component: Market Motivations & $.743(.324 ; 2.101)^{*}$ \\
\hline Ease of getting to the grocery store & $-.730(.231 ; .482)^{* *}$ \\
\hline \# of children in house & $.454(.231 ; 1.574)^{* *}$ \\
\hline Attendance at FM as a youth & n.s. \\
\hline Frequency in shopping at BCFM & n.s. \\
\hline Q10 Overall Component: Benefits of shopping at the FM & n.s. \\
\hline Q17 Component 1: Pure food & n.s. \\
\hline Q17 Component 2: Locally good food & n.s. \\
\hline Usual transportation mode to grocery & n.s. \\
\hline Number of household members & n.s. \\
\hline Gender & n.s. \\
\hline Age & n.s. \\
\hline Religiosity & n.s. \\
\hline Miles to market & n.s. \\
\hline Constant & $-1.063(1.572 ; .345)$ \\
\hline AIC & 236.104 \\
\hline
\end{tabular}

S.E. Standard Error; $* * * p<.001 ; * * p<.01 ; * p<.05 ;$ n.s. $=$ not significant
SNAP user did as well. This relationship is quantified via the odds ratio. For example, for one unit decrease in the ease of getting to the grocery store, the likelihood of someone being a SNAP user increased. Thus, the probability that a respondent will be a SNAP user increased by $43.5 \%$ for every unit decrease reported in the ease of getting to the grocery store. For the Q9 composite variable (market motivations), for each point higher (on the Likert scale) one's score moves, one is $10.9 \%$ more likely to be a SNAP user. Alternatively, for each dollar less (out of pocket) someone spent at the farmers market, he or she is $29.7 \%$ more likely to be a SNAP user. Finally, for each additional child in the household, one is $18.1 \%$ more likely to be a SNAP user.

\section{Discussion}

This article centers on the nexus of demographics, motives, and experiential similarities and differences between farmers market SNAP and nonSNAP users, as well as SNAP users who do and do not go to the farmers market. O ur results provide five salient points for further consideration and discussion.

First, the demographics of our survey respondents support some common findings in the literature while also shedding light on new insights: BCFM shoppers are predominantly female, White, and middle-aged. We also find that the majority have at least one child in the household and are likely to attend religious services at least once per year. A key difference in our current work compared to the 
literature is the potential utility of religiosity in food justice movements. We found that SNAP users not attending the market participated more frequently in religious services than those SNAP users who frequent the farmers market. This finding is critical as religious affiliation can provide an avenue for communication; information about the farmers market--e.g., hours, location, foods available, SNAP use, prices, etc.--can be distributed through religious networks. Additionally, our comparison of SNAP and non-SNAP users at the farmers market, a new addition to the literature, reveals anticipated differences in educational attainment, ethnicity, and household income, as well as significant differences in gender, age, household size, and the number of children in the household. SNAP users at the market are younger, have more children, a larger household size, and are even more likely to be female. As expected, SNAP users that do not attend the market have lower household incomes and lower educational attainment and represent a more racially and ethnically diverse demographic. Of critical importance are the results highlighting the similarities and difference between SNAP users who attend the BCFM and those who live in the same city but do not attend. Specifically, the difference in the educational attainment and income results between SNAP users who attend the farmers market and those who do not is stark. The number of market-going SNAP users with degrees above a high school diploma (or equivalent) is quite large compared to non-market attending SNAP users. This is a critical finding for consideration as it suggests that education is a strong correlate to market attendance, at least at the BCFM. Likewise, the income level of the two groups is also vastly different. While both SNAP groups have relatively low-income levels, the results for those attending the BCFM show uniformity across low-income brackets than SNAP users not attending the market (which are grouped towards the lower end of the economic spectrum).

Second, transportation issues appear to be a challenge or barrier for both SNAP groups when compared to the non-SNAP users attending the market. The lack of a personal automobile is a recurring factor contributing to food insecurity among low-income households located relatively far from food outlets (Walker et al., 2010). We used the question on the difficulty of getting to the grocery store as a proxy for transportation as a barrier. There were significant differences between non-market going SNAP users, market going SNAP, and nonSNAP users. Non-SNAP users found it easiest to get to the grocery, and market-going SNAP users followed suit. O ur regression results (Table 5) show that the ease of getting to the grocery store was a major influence distinguishing SNAP users from non-SNAP users. Some research has found market attendees to be willing to travel farther to get to a market compared to those shopping solely at grocery stores (Parks et al., 2018); thus, we posit transportation as a critical barrier to examine when considering market placement and barriers to accessing local foods (Markowitz, 2010).

Third, SNAP users reported a greater variety of fresh fruits and vegetables consumed at home as a result of their participation in the farmers market. O ur comparative analysis of SNAP and non-SNAP users reveals that only the SNAP group has increased their fresh fruit and vegetable consumption. Additionally, the variety within the food groups has also increased for the SNAP population. Moreover, SNAP users report that the D MBP has been "very important" for them and contributes to their decision to spend SNAP benefits at the BCFM. This suggests that financial incentives are increasing the health and food security of SNAP users in attendance at the farmers market. Interestingly, the vast majority of the SNAP users we surveyed claim that they would still participate in the BCFM even if SNAP were no longer accepted.

Both market-attending groups have similar out-of-pocket expenses (not including SNAP or matching funds). Considering the additional use of Market Bucks, this implies that SNAP users are spending more at the market in total. In fact, SNAP users purchased significantly more fruits, meat, dairy, eggs, honey, and other dairy products than their non-SNAP counterparts. O nly bread was purchased less often by SNAP users, and vegetable purchases were not significantly different between the two groups. Thus, it is assumed that cascading nutritional benefits exist due to the increase in take-home products from the market 
due to the DMBP. These findings corroborate the claim of many SNAP users that the DMBP is "very important" as an influencer to spend SNAP benefits at the market. These findings also suggest that the farmers market has become an important food outlet for SNAP users who attend the market.

Fourth, with regard to motivations for participation, there were more similarities than differences between SNAP and non-SNAP users at the farmers market. This underlines the importance of local, organic, sustainable foods to farmers market shoppers, regardless of household income. Motives for attending the market were all similar, with two initial exceptions. First, SNAP users claimed "learning about farming and gardening" to be a motivation significantly more often than nonSNAP users. This reveals that the farmers market is more than simply a food outlet; it is also an educational resource and a community of practice. Second, SNAP users claimed more often to attend the market "to purchase food inexpensively." One possible explanation for this is that the SNAP benefits and the doubling of SNAP benefits drives down the prices for SNAP recipients by subsidizing their purchases.

Finally, we found SNAP users to report strong values for items often associated with purchasing food from farmers markets. Although not significant for all categories, SNAP users ranked the majority of these values (e.g., organic, freshness, humaneness) higher than non-SNAP users who attended the market. One statistically significant difference between the two groups was the belief that "consuming foods produced locally is better for the environment." This was valued higher by SNAP users. Considering the greater number and severity of the challenges experienced by SNAP users attending the farmers market, we consider it likely that their participation requires higher values attributed to the foods available there. It may be necessary for SNAP households to value local foods in order to overcome the disproportionately higher number of access barriers they experience compared to non-SNAP households (e.g., transportation, price, etc.). O verall, the lack of differences in values of the two groups again reveals the importance of local food for both SNAP and nonSNAP users. This suggests that the implementation of financial incentives at farmers markets may reduce certain access barriers for SNAP participants but may not attract SNAP users that do not have a high value for local foods.

There are key limitations of this study that merit further discussion. First, this research relies solely on survey work; we did not observe the behavior of participants at the market or conduct interviews, both of which would provide more depth to complement the breadth of our results. Participant observation and in-depth interviews would help us further assess the individual barriers people face as well as how to facilitate engagement. Along these same lines, we performed this research in a small Midwestern city with a single, dominant market. While this is helpful to understand how such a scenario attracts and retains different types of users, research that includes numerous sites from across a city or larger metro area would also be beneficial. Finally, future research should further address the ease of getting to the grocery store as a proxy for transportation barriers. Items such as transportation issues, store preference, and hours of operation could comprise a broader factor.

\section{Conclusion}

O verall, this study found that the acceptance of SNAP benefits at the farmers market benefits a segment of the SNAP population. Those using SNAP at farmers markets share many similarities with non-SNAP farmers market customers. There are also several differences between SNAP recipients who attend the market and those who do not. Additionally, we found that SNAP users are able to acquire similar or greater amounts of fresh, farmers market products compared to non-SNAP market attendees while spending about 17.7\% less out-ofpocket than non-SNAP market attendees. Finally, we contend that transportation, or alternatively geographic placement, is a critical issue for SNAP recipients, particularly in a city with a single focal market that is centrally located away from and not adjacent to residential areas characterized by lowincome households.

O ur results have four primary professional implications for those working on farmers market participation (and local food systems), particularly 
pertaining to the inclusion of low-income households. First, the results underscore, at least for this population, how economic incentives are a critical means for enhancing access to local fresh fruits and vegetables by subsidizing further purchasing power for low-income individuals. The majority of our respondents would attend the market without the acceptance of SNAP benefits (albeit likely going home with less product). Thus, if market organizers are interested in recruiting individuals who would normally not attend the market, our results point to transportation ease and geographic placement as critical elements for consideration. Offering smaller, satellite markets may help alleviate this barrier. Second, our results, particularly when compared against our earlier neighborhood survey (Phase 1), indicate that the market-attending SNAP users are more similar (with respect to specific variables) to the market-attending non-SNAP users than they are to SNAP users who do not frequent the market. This notion implicates the need to consider cultural fit at the market and how the market's own culture may attract or repel individuals. That said, farmers markets are not panaceamarketing ventures for attracting all individuals, and a diversity of distribution and procurement options are critical to bolstering accessibility and inclusion in a local food system. Third, this research highlights the nutritional benefit and impact of market bucks programs. Having a double-buck program suppresses financial barriers while simultaneously prompting people to purchase local, healthy food. Finally, food system professionals may want to consider how to network with and through faith-based organizations. In this way, they can take advantage of the systems already in place that are serving as critical safety nets for food security for low-income households. O ne prime example is the Fresh Stop Market organized out of the Shawnee Presbyterian Church in Louisville, Kentucky. Fresh Stop runs a host of fresh-food pop-up markets that distribute through institutions located in food-insecure neighborhoods. Churches are a common venue for this organization.

Working within a food justice framework requires more than simply increasing financial access to food; managers must also consider the types of food available at the market and the values advertised and addressed by the managers of this food space. While recognizing that farmers markets may not be culturally appropriate or desirable for all households, communities should continue to assess both the accessibility of farmers markets to interested households and the acceptability of other localization strategies to those not interested in the farmers market. Therefore, we encourage professionals and researchers to collaboratively work with low-income neighborhoods as part of any food localization initiative. D oing such will allow residents to share their views about which food values are important. It also allows professionals and researchers to consider other desirable connections between low-income households and local foods. As every community differs in needs, resources, and culture, we contend that the Community Based Participatory Research approach remains a critical way forward.

\section{Acknowledgments}

We thank the City of Bloomington Parks and Recreation D epartment for allowing us to collect data at the market. We also appreciate comments from the reviewers and editor who provided invaluable feedback on the manuscript.

\section{References}

Alkon, A. H. (2012). Black, white, and green: Farmers mark ets, raœ, and the green exnomy. Athens: University of G eorgia Press.

Allen, P. (1999). Reweaving the food security safety net: Mediating entitlement and entrepreneurship. A griaulture and H uman V alues, 16(2), 117-129. https:// doi.org/ 10.1023/ A:1007593210496

Babb, A. M. (2013). C ommunity food seaurity: The role of alternative food networks in food deserts (Unpublished Master's thesis). Indiana University, Bloomington, Indiana, USA.

Bell, J., Mora, G., Hagan, E., Rubin, V., \& Karpyn, A. (2013). A coess to healthy food and why it matters: A review of the literature. Policy Link and The Food Trust. Retrieved from http:/ / thefoodtrust.org/ uploads/ media items/ access-to-healthyfood.original.pdf 
Journal of Agriculture, Food Systems, and Community Development

ISSN: 2152-0801 online

https:/ / www.foodsystemsjournal.org

Bowling, A., Moretti, M., Ringelheim, K., Tran, A., D avison, M. (2016). Healthy foods, healthy families: Combining incentives and exposure interventions at urban farmers' markets to improve nutrition among recipients of US federal food assistance. H ealth Promotion Perspectives, 6(1), 10-16. https:/ / doi.org/ 10.15171/ hpp.2016.02

City of Bloomington. (2016). Bloomington Census D ata. Retrieved from https:// bloomington.in.gov/ about/ census-data

Colasanti, K., Conner, D ., \& Smalley, S. (2010). Understanding barriers to farmers' market patronage in Michigan: Perspectives from marginalized populations. Journal of $\mathrm{H}$ unger \& E nvironmental $\mathrm{N}$ utrition, 5(3), 316-338. https:/ / doi.org/ 10.1080/ 19320248.2010.504097

Cummings, H., Kora, G., \& Murray, D . (1999). Community and economic impact of farmers' mark ets in Ontario: Summary report. Guelph, ON: University of Guelph, School of Rural Planning and D evelopment. Retrieved from http:/ / hcaconsulting.ca/ wp-content/ uploads/ 2017/ 03/ 1999-Farmers-Markets-Ontario-Economic-Impact.pdf

DeLind, L. B. (2006). Of bodies, place, and culture: Re-situating local food. Journal of A griaultural and E nvironmental E thics, 19(2), 121-146. https:/ / doi.org/ 10.1007/ s10806-005-1803-z

Dimitri, C., O berholtzer, L., Zive, M., \& Sandolo, C. (2015). Enhancing food security of low-income consumers: An investigation of financial incentives for use at farmers markets. F ood Policy, 52, 64- 70. https:// doi.org/ 10.1016/j.foodpol.2014.06.002

Farmer, J. R., Chancellor, C. H., G ooding, A., Shubowitz, D ., \& Bryant, A. (2011). A tale of four farmers markets: Recreation and leisure as a catalyst for sustainability. Journal of Park and Recreation A dministration, 29(3), 11-23.

Farmer, J. R., Chancellor, C., Robinson, J. West, S., \& Weddell, M. (2014). Agrileisure: Farmers' markets, CSAs, and the privilege in eating local. Journal of L eisure Research, 46(3), 313-328. https:/ / doi.org/ 10.1080/ 00222216.2014.11950328

Farmer, J. R., Minard, S., \& Edens, C. (2016). Local foods and low-income communities: Location, transportation, and values. Journal of A griculture, Food Systems, and Community D evelopment, 6(4), 41-53. https:// doi.org/ 10.5304/ jafscd.2016.064.009

Field, A. (2013). D iscovering Statistics Using IBM SPSS (4th edition). Thousand Oaks, CA: SAGE Publications.

Fortman, L. (2008). D oing science together. In L. Fortmann (Ed.), Participatory research in conservation and rural livelihoods: D oing science together (pp. 1-17). Oxford, UK: Wiley-Blackwell.

Garrett, H. (2014). Eating local: A cost analysis of farmers' market vs. store-bought foods in A sheville, North Carolina. Journal of U ndergraduate Research [University of North Carolina at Asheville], 2014(May), 465-474. Retrieved from https:/ / libres.uncg.edu/ ir/ unca/ f/ H_ G arrett_Eating_JrnlUngRes_2014pdf.pdf

Godfray, H. C. J., Beddington, J. R., Crute, I. R., Haddad, L., Lawrence, D ... . Toulmin, C. (2010). Food security: The challenge of feeding 9 billion people. Scienœ, 327(5967), 812-818. https:/ / doi.org/ 10.1126/ science.1185383

Guthman, J. (2008). If they only knew: Color blindness and universalism in California alternative food institutions. The Professional G eographer, 60 (3), 387-397. https:/ / doi.org/ 10.1080/ 00330120802013679

Herman, D . R., Harrison, G. G ., Afifi, A. A., \& Jenks, E. (2008). Effect of a targeted subsidy on intake of fruits and vegetables among low-income women in the Special Supplemental Nutrition Program for Women, Infants, and Children. A merican Journal of Public H ealth, 98(1), 98-105. https:/ / doi.org/ 10.2105/ AJPH.2005.079418

Hicks, K., \& Lambert-Pennington, K. (2014). Evaluating the South Memphis Farmers Market as a strategy to improve access to healthy foods: Lessons from 2011. Journal of A griaulture, Food Systems, and Community D evelopment, 4(2), 45-59. http:// dx.doi.org/ 10.5304/ jafscd.2014.042.014

Hinrichs, C. C. (2000). Embeddedness and local food systems: Notes on two types of direct agricultural market. Journal of Rural Studies, 16(3), 295-303. https:/ / doi.org/ 10.1016/ S0743-0167(99)00063-7

Hinrichs, C., \& Kremer, K. S., (2002). Social inclusion in a Midwest local food system project. Journal of Poverty, 6(1), 6590. https:// doi.org/ 10.1300/J134v06n01_04

Jones, P. \& R. Bhatia (2011). Supporting equitable food systems through food assistance at farmers' markets. A merican Journal of Public H ealth, 101(5), 781-783. https:// doi.org/ 10.2105/ AJPH.2010.300021

Kantor, L. S. (2001). Community food security programs improve food access. Food Review-W ashington D C , 24(1), 20-26.

La Trobe, H. (2001). Farmers' markets: consuming local rural produce. International Journal of Consumer Studies, 25(3), 181192. https:/ / doi.org/ 10.1046/ j.1470-6431.2001.00171.x 
Lay, K. (2014). D ouble M ark et Bucks Program: Reducing local food insearity and strengthening the local food economy. Bloomington Parks and Recreation Department.

Leone, L. A., Beth, D., Ickes, S. B., MacG uire, K., Nelson, E., Smith, R. A., ... Ammerman, A. S. (2012). Attitudes toward fruit and vegetable consumption and farmers' market usage among low-income North Carolinians. Journal of H unger \& E nvironmental N utrition, 7(1), 64-76. https:// doi.org/ 10.1080/ 19320248.2012.651386

Lindsay, S., Lambert, J., Penn, T, Hedges, S., Ortwine, K., Mei, A., ... Wooten, W. J. (2013). Monetary matched incentives to encourage the purchase of fresh fruits and vegetables at farmers markets in underserved communities. Preventing Chronic D isease, 10, E188. https:/ / doi.org/ 10.5888/ pcd10.130124

Lucan, S. C., Maroko, A. R., Sanon, O ., Frias, R., \& Schechter, C.B. (2015). Urban farmers' markets: Accessibility, offerings, and produce variety, quality, and price compared to nearby stores. A ppetite, 90(1), 23-30. https:// doi.org/ 10.1016/ j.appet.2015.02.034

Markowitz, L. (2010). Expanding access and alternatives: building farmers' markets in low-income communities. Food and Foodways, 18(1-2), 66-80. https:/ / doi.org/ 10.1080/ 07409711003708512

Mann, J., Miller, S., O’Hara, J., G oddeeris, L. Pirog, R., \& Trumbull, E. (2018). Healthy food incentive impacts on directto-consumer sales: A Michigan example. Journal of A griaulture, F ood Systems, and Community D evelopment, 8(1), 97-112. https:// doi.org/ 10.5304/ jafscd.2018.081.006

McD aniel, L. (2014, September 12). A re farmers' mark et prices really more ex pensive? E at L ocal Placer N evada. Retrieved September 10, 2018, from http:/ / ucanr.edu/ blogs/ blogcore/ postdetail.cfm?postnum=15299

O berholtzer, L., \& G row, S. (2003). Producer only farmers' mark ets in the mid-A tlantic region: A survey of mark et managers. A rlington, VA: Wallace Center at Winrock International.

O berholtzer, L., D imitri, C., \& Schumacher, G. (2012). Linking farmers, healthy foods, and underserved consumers: Exploring the impact of nutrition incentive programs on farmers and farmers' markets. Journal of A griculture, F ood Systems, and Community D evelopment, 2(4), 63- 77. http:// dx.doi.org/ 10.5304/ jafscd.2012.024.002

Parks, C. A., Jaskiewicz, L. J., D ombrowski, R. D., Fricke, H. E., Hortman, S. B., Trumbull, E., ... Yaroch, A. L. (2018). What characteristics define participants of Michigan's Healthy Food Incentive Program? Journal of Planning E ducation and Research. Advance online publication. https:// doi.org/ 10.1177/ 0739456X 18772081

Payne, G. H., Wethington, H., Olsho, L., Jernigan, J., Farris, R., \& Walker, D . K. (2013). Implementing a farmers' market incentive program: Perspectives on the New Y ork City Health Bucks Program. Preventing C hronic D isease, 10, E145. https:// doi.org/ 10.5888/ pcd10.120285

Sadler, R. (2016). Strengthening the core, improving access: Bringing healthy food downtown via a farmers' market move. A pplied G eography, 67, 119-218. https:/ / doi.org/ 10.1016/ j.apgeog.2015.12.010

Seyfang, G . (2006). Ecological citizenship and sustainable consumption: Examining local organic food networks. Journal of Rural Studies, 22(4), 383-395. https:/ / doi.org/ 10.1016/ j.jrurstud.2006.01.003

Singleton, C.R., Sen, B., \& Affuso, O . (2015). D isparities in the availability of farmers markets in the United States. E nvironmental Justiœ, 8(4), 135-143. https:/ / doi.org/ 10.1089/ env.2015.0011

Slocum, R. (2008). Thinking race through corporeal feminist theory: Divisions and intimacies at the Minneapolis Farmers' Market. Social \& C ultural G eography, 9(8), 849-869. https:/ / doi.org/ 10.1080/ 14649360802441465

Strand, K., Marullo, S., Cutforth, N., Stoecker, R., \& D onohue, P. (2003). C ommunity-based research and higher education. San Francisco: Jossey-Bass.

Tiehen, L., Jolliffe, D., \& G undersen, C. (2012). A lleviating poverty in the U nited States: The critical role of SN A P benefits (Report ERR-132). U.S. D epartment of Agriculture, Economic Research Service. Retrieved from https:// www.ers.usda.gov/ publications/ pub-details/ ?pubid $=44965$

United States D epartment of Agriculture, Agricultural Marketing Service. (2015). L ocal food directories: N ational F armers M ark et D irectory. Retrieved from http:/ / www.ams.usda.gov/ local-food-directories/ farmersmarkets

Vermont Agency of Agriculture, Food and Markets. (2016). A comparison study of product pricing at $V$ ermont farmers' mark ets and retail establishments. Retrieved from http:/ / agriculture.vermont.gov/ sites/ ag/ files/ pdf/ local food data/Completed\%20Fixed-\%20SO V\%20Consumer \%20G uide\%20to\%20Purchasing\%20Food\%20at\%20Farmers\%27\%20Market....pdf 
Walker, R. E., Keane, C. R., \& Burke, J. G . (2010). Disparities and access to healthy food in the United States: A review of food deserts literature. H ealth \& Plaœ, 16(5), 876-884. https:/ doi.org/ 10.1016/ j.healthplace.2010.04.013

Winch, R. (2008). N utrition inœentives at farmers' mark ets: Bringing fresh, healthy, local foods within reach. Cockeysville, MD: Farmers Market Coalition. Retrieved from http:// www.farmlandinfo.org/ sites/default/ files/ ebt matching_programs rachel winch_1.pdf

Wolf, M., Spittler, A., \& Ahern, J. (2005). A profile of farmers' market consumers and the perceived advantages of produce sold at farmers' markets. Journal of F ood D istribution Research, 36(1), 192-201. Retrieved from https:/ / ageconsearch.umn.edu/ record/ 26768?!n=en

Wooten, N. (2013). D ouble M ark et Bucks Program: Reducing local food inseaurity and strengthening the local food economy. Bloomington, IN: Parks and Recreation D epartment. Retrieved from http:/ / issuu.com/ bloomingtonparks/ docs/ double market bucks 2013 annual rep

Zepeda, L. (2009). Which little piggy goes to market? Characteristics of US farmers' market shoppers. International Journal of Consumer Studies, 33(3), 250-257. https:/ / doi.org/ 10.1111/ j.1470-6431.2009.00771.x 


\section{Appendix A. Demographic Results and Comparison between N eighborhood Groups}

\begin{tabular}{|c|c|c|c|c|c|c|}
\hline Variables & Overall & $\begin{array}{c}\text { FM SNAP } \\
\text { Users } \\
(\mathrm{n}=89)\end{array}$ & $\begin{array}{c}\text { Non-SNAP } \\
\text { Users } \\
(\mathrm{n}=160)\end{array}$ & $\begin{array}{c}\text { Phase } 1 \\
\text { SNAP Users } \\
(n=50)^{a}\end{array}$ & $\begin{array}{c}\text { p-value } \\
\text { between } \\
\text { FM SNAP \& } \\
\text { Non-SNAP }\end{array}$ & $\begin{array}{c}\text { p-value } \\
\text { between } \\
\text { FM SNAP \& } \\
\text { Phase 1 SNAP }\end{array}$ \\
\hline Gender & & & & & .165 & $.000 * * * *$ \\
\hline Male & $25.2 \%$ & $17.98 \%$ & $29.38 \%$ & $33.33 \%$ & & \\
\hline Female & $73.6 \%$ & $79.78 \%$ & $69.38 \%$ & $66.70 \%$ & & \\
\hline Other & $1.2 \%$ & $0.00 \%$ & $1.25 \%$ & $0 \%$ & & \\
\hline Mean Age & 42.54 & 39.68 & 44.08 & 43.20 & $.070^{*}$ & .377 \\
\hline Household Size & 2.68 & 3 & 2.53 & 2.75 & $.065^{*}$ & .601 \\
\hline Children in household & $44.5 \%$ & 1.34 & .62 & .52 & $.000 * * * *$ & .839 \\
\hline Educational Attainment & & & & & $.000 * * * *$ & $.000 * * * *$ \\
\hline Did Not Finish High School & $2.8 \%$ & $5.62 \%$ & $1.25 \%$ & $35.30 \%$ & & \\
\hline High School or GED & $9.2 \%$ & $13.48 \%$ & $6.88 \%$ & $33.30 \%$ & & \\
\hline Some College & $18.4 \%$ & $24.72 \%$ & $15.00 \%$ & $17.60 \%$ & & \\
\hline Associate's or Technical Degree & $10.8 \%$ & $15.73 \%$ & $8.13 \%$ & $5.90 \%$ & & \\
\hline Bachelor's Degree & $27.6 \%$ & $24.72 \%$ & $28.75 \%$ & $5.90 \%$ & & \\
\hline Master's Degree & $22.8 \%$ & $12.36 \%$ & $28.75 \%$ & $2.00 \%$ & & \\
\hline Professional/ Doctoral Degree & $8.4 \%$ & $2.25 \%$ & $11.25 \%$ & $0.00 \%$ & & \\
\hline Ethnicity & & & & & $.082 *$ & .530 \\
\hline African American or Black & $4.0 \%$ & $6.74 \%$ & $2.50 \%$ & $13.70 \%$ & & \\
\hline American Indian or Alaska Native & $0.8 \%$ & $2.25 \%$ & $0 \%$ & $2.00 \%$ & & \\
\hline Asian & $4.8 \%$ & $3.37 \%$ & $5.63 \%$ & $3.90 \%$ & & \\
\hline Hispanic & $3.6 \%$ & $5.62 \%$ & $2.50 \%$ & $3.90 \%$ & & \\
\hline White & $86.0 \%$ & $80.90 \%$ & $88.13 \%$ & $74.5 \%$ & & \\
\hline Other & $0.8 \%$ & $0 \%$ & $1.25 \%$ & $2.00 \%$ & & \\
\hline Household Income Level (all US\$) & & & & & $.000 * * *$ & $.002 * * *$ \\
\hline$\$ 0-\$ 15,000$ & $24.6 \%$ & $44.94 \%$ & $11.88 \%$ & $74.50 \%$ & & \\
\hline$\$ 15,001-\$ 30,000$ & $23.3 \%$ & $41.57 \%$ & $11.25 \%$ & $11.70 \%$ & & \\
\hline$\$ 30,001-\$ 45,000$ & $12.9 \%$ & $11.24 \%$ & $13.13 \%$ & $2.00 \%$ & & \\
\hline$\$ 45,001-\$ 60,000$ & $8.8 \%$ & $0 \%$ & $12.50 \%$ & $0 \%$ & & \\
\hline$\$ 60,001-\$ 75,000$ & $7.9 \%$ & $0 \%$ & $11.25 \%$ & $0 \%$ & & \\
\hline$\$ 75,001-\$ 90,000$ & $3.8 \%$ & $0 \%$ & $5.00 \%$ & $0 \%$ & & \\
\hline$\$ 90,001-\$ 120,000$ & $7.9 \%$ & $0 \%$ & $11.88 \%$ & $0 \%$ & & \\
\hline$\$ 120,001-\$ 150,000$ & $3.8 \%$ & $0 \%$ & $5.63 \%$ & $0 \%$ & & \\
\hline$\$ 150,001-\$ 180,000$ & $2.5 \%$ & $0 \%$ & $3.75 \%$ & $0 \%$ & & \\
\hline$\$ 180,001-\$ 250,000$ & $3.3 \%$ & $0 \%$ & $5.00 \%$ & $0 \%$ & & \\
\hline$\$ 250,001+$ & $1.3 \%$ & $0 \%$ & $1.88 \%$ & $0 \%$ & & \\
\hline Religiosity & & & & & .92 & $.000 * * * *$ \\
\hline Weekly Attendance & $22.4 \%$ & $20.22 \%$ & $23.13 \%$ & $30.20 \%$ & & \\
\hline 2 to 3 Times per Month & $4.9 \%$ & $3.37 \%$ & $5.00 \%$ & $0.00 \%$ & & \\
\hline Monthly & $5.3 \%$ & $5.62 \%$ & $5.00 \%$ & $7.50 \%$ & & \\
\hline Several Times a Year & $12.2 \%$ & $15.73 \%$ & $10.00 \%$ & $11.30 \%$ & & \\
\hline Yearly & $12.2 \%$ & $12.36 \%$ & $11.88 \%$ & $5.70 \%$ & & \\
\hline Never & $43.1 \%$ & $37.08 \%$ & $45.00 \%$ & $45.30 \%$ & & \\
\hline
\end{tabular}

(ontinued) 
Journal of Agriculture, Food Systems, and Community Development ISSN: 2152-0801 online

https:/ / www.foodsystemsjournal.org

\begin{tabular}{|c|c|c|c|c|c|c|}
\hline Variables & Overall & $\begin{array}{c}\text { FM SNAP } \\
\text { Users } \\
(n=89)\end{array}$ & $\begin{array}{c}\text { Non-SNAP } \\
\text { Users } \\
(n=160)\end{array}$ & $\begin{array}{l}\text { Phase } 1 \\
\text { SNAP Users } \\
\quad(n=50)^{a}\end{array}$ & $\begin{array}{c}\text { p-value } \\
\text { between } \\
\text { FM SNAP \& } \\
\text { Non-SNAP }\end{array}$ & $\begin{array}{c}\text { p-value } \\
\text { between } \\
\text { FM SNAP \& } \\
\text { Phase } 1 \text { SNAP }\end{array}$ \\
\hline Difficulty in getting to grocery store & & & & & $.003 * * *$ & $.012 * *$ \\
\hline Very Difficult & $2.0 \%$ & $4.5 \%$ & $0.00 \%$ & $20.80 \%$ & & \\
\hline Difficult & $9.9 \%$ & $18.2 \%$ & $5.60 \%$ & $24.50 \%$ & & \\
\hline Easy & $39.3 \%$ & $38.6 \%$ & $40.10 \%$ & $35.80 \%$ & & \\
\hline Very Easy & $48.0 \%$ & $36.3 \%$ & $54.30 \%$ & $18.90 \%$ & & \\
\hline Mean & 3.34 & 3.11 & 3.47 & 2.53 & & \\
\hline
\end{tabular}

a Phase 1 SNAP user data was derived from a neighborhood survey conducted in three locales in Bloomington, IN. Further details on this phase of the study can be found in Author Paper (Farmer et al., 2016).

$* \mathrm{p}<.1 ; * * \mathrm{p}<.05 ; * * * \mathrm{p}<.01 ; * * * * \mathrm{p}<.001$ 
Journal of Agriculture, Food Systems, and Community D evelopment ISSN : 2152-0801 online https:/ / www.foodsystemsjournal.org

Appendix B. Survey Instrument: 2015 Bloomington Community Farmers' Market Survey (following pages) 


\section{Bloomington Community Farmers' Market Survey}

\section{Section 1: Farmers' market experience}

1. While you were growing up, how often did you or your family shop at the following:

\begin{tabular}{|l|l|l|l|l|l|l|}
\hline & Never & Yearly & Quarterly & Monthly & $\begin{array}{c}\text { Couple X } \\
\text { a Month }\end{array}$ & Weekly \\
\hline Farmers' Market & & & & & & \\
\hline Roadside Stand & & & & & & \\
\hline U-pick Farm & & & & & & \\
\hline
\end{tabular}

2. How many times per month do you shop at the Bloomington Community Farmers' Market (BCFM)?

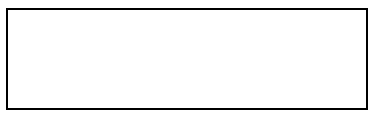

3. What products do you most commonly purchase at the BCFM? (Select all that apply)

\begin{tabular}{|l|l|l|}
\hline$\square$ Fruits & $\square$ Meat & $\square$ Ready-made foods \\
\hline$\square$ Vegetables & $\square$ Cheese & $\square$ Other: \\
\hline$\square$ Bread & $\square$ Other Dairy & $\square$ Other: \\
\hline$\square$ Honey & $\square$ Eggs & $\square$ Other: \\
\hline
\end{tabular}

4. As a result of shopping at the farmers' market, the:

\begin{tabular}{|l|l|l|l|l|l|}
\hline & $\begin{array}{c}\text { Increased } \\
\text { Greatly }\end{array}$ & $\begin{array}{c}\text { Increased } \\
\text { Some }\end{array}$ & $\begin{array}{c}\text { Stayed the } \\
\text { same }\end{array}$ & $\begin{array}{c}\text { Decreased } \\
\text { Some }\end{array}$ & $\begin{array}{c}\text { Decreased } \\
\text { Greatly }\end{array}$ \\
\hline $\begin{array}{l}\text { f...amount of fresh } \\
\text { fruits and } \\
\text { vegetables I eat has }\end{array}$ & & & & & \\
\hline $\begin{array}{l}\text {...variety of fresh } \\
\text { fruits and } \\
\text { vegetables I eat has }\end{array}$ & & & & & \\
\hline
\end{tabular}

5. Do you find enough vendors selling the foods you want?

6. How many years have you been attending the BCFM?

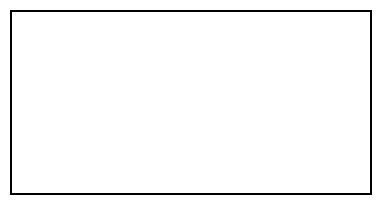

PID: 


\section{Bloomington Community Farmers' Market Survey}

7. Are you satisfied with the variety of foods available for purchase?

If no, what additional foods would you like to see for sale?

8. How much money do you generally spend at the BCFM each visit (excluding SNAP or WIC benefits)?

9. Please indicate your level of agreement for the following statements on a scale from Strongly Disagree (SD), Disagree (D), Neutral (N), Agree (A), to Strongly Agree (SA).

\begin{tabular}{|c|c|c|c|c|c|}
\hline I go to the farmers' market because I want... & SD & D & $\mathbf{N}$ & $\mathbf{A}$ & SA \\
\hline \multicolumn{6}{|l|}{ Fresh food } \\
\hline \multicolumn{6}{|l|}{ Food with higher nutritional value } \\
\hline \multicolumn{6}{|l|}{ Food with fewer synthetic chemicals } \\
\hline \multicolumn{6}{|l|}{ More variety } \\
\hline \multicolumn{6}{|l|}{ Easier access to buying fresh food } \\
\hline \multicolumn{6}{|l|}{ To purchase foods inexpensively } \\
\hline \multicolumn{6}{|l|}{ To learn about farming or gardening } \\
\hline \multicolumn{6}{|l|}{ Recreation opportunities } \\
\hline \multicolumn{6}{|l|}{ To consume foods grown sustainably } \\
\hline \multicolumn{6}{|l|}{ To support sustainable farming practices } \\
\hline \multicolumn{6}{|l|}{ To support a local food system } \\
\hline To support local farmers & & & & & \\
\hline
\end{tabular}

10. Please indicate your level of agreement for the following statements on a scale from Strongly Disagree (SD), Disagree (D), Neutral (N), Agree (A), to Strongly Agree (SA).

\begin{tabular}{|l|l|l|l|l|l|}
\hline $\begin{array}{l}\text { The benefits I receive from attending the farmers' } \\
\text { market include: }\end{array}$ & SD & D & N & A & SA \\
\hline Nutritional food & & & & & \\
\hline Sense of belonging & & & & & \\
\hline Fresh food & & & & & \\
\hline Convenience & & & & & \\
\hline Opportunity for recreation & & & & & \\
\hline Social interaction with friends & & & & & \\
\hline Knowing how my food was grown & & & & & \\
\hline Safe food &
\end{tabular}




\section{Bloomington Community Farmers' Market Survey}

11. Do you receive SNAP benefits (food stamps)?

\section{No (Please move on to question \#17)}

\section{Yes}

12. About how many times per month do you use Market Bucks at the Saturday BCFM? (check one)
This is my first time
Once a month
2-3 times a month
$\square$ Every Saturday

13. How important is the Double Market Bucks program in your decision to spend SNAP benefits at this farmers' market?
Very
Moderately important
Slightly important
Not important

14. If SNAP benefits were not accepted at the market, would you continue to shop at the BCFM?

\section{No}

\section{Yes}

15. How many SNAP/EBT dollars do you redeem each month at the BCFM?

\section{(do not include Market Bucks in this number)}

16. How did you learn about Double Market Bucks program?

At the farmers' market (from staff or poster/advertisement)

Farmers' market website or Facebook

A friend or family member

Newspaper or radio

Local soup kitchen or food pantry

From a social service agency

Other: 


\section{Bloomington Community Farmers' Market Survey}

\section{Section 2: Food Values and Household Behavior}

17. Please rate your level of agreement with the following statements concerning local foods: Strongly Disagree (SD), Disagree (D), Neutral (N), Agree (A), to Strongly Agree (SA).

\begin{tabular}{|c|c|c|c|c|c|}
\hline & SD & $\begin{array}{l}\mathbf{D} \\
\boldsymbol{\nabla}\end{array}$ & $\begin{array}{l}\mathbf{N} \\
\nabla\end{array}$ & $\begin{array}{l}\text { A } \\
\nabla\end{array}$ & SA \\
\hline Purchasing organically grown food is very important to me. & $\square$ & $\square$ & $\square$ & $\square$ & $\square$ \\
\hline I give preference to foods that are grown with few chemical applications. & $\square$ & $\square$ & $\square$ & $\square$ & $\square$ \\
\hline $\begin{array}{l}\text { I give preference to foods that were picked just a few days before my } \\
\text { purchase. }\end{array}$ & $\square$ & $\square$ & $\square$ & $\square$ & $\square$ \\
\hline $\begin{array}{l}\text { I would prefer that all Genetically Modified Organism (GMO) foods sold at } \\
\text { the Bloomington Community Farmers' Market be labeled. }\end{array}$ & $\square$ & $\square$ & $\square$ & $\square$ & $\square$ \\
\hline $\begin{array}{l}\text { The nutritional value of a food is an important part of my purchasing } \\
\text { decisions. }\end{array}$ & $\square$ & $\square$ & $\square$ & $\square$ & $\square$ \\
\hline $\begin{array}{l}\text { I give preference to animal products that have been derived in a humane } \\
\text { manner. } \square \text { Not applicable (I'm vegan) }\end{array}$ & $\square$ & $\square$ & $\square$ & $\square$ & $\square$ \\
\hline I give preference to animal products that are free from growth hormones. & $\square$ & $\square$ & $\square$ & $\square$ & $\square$ \\
\hline $\begin{array}{l}\text { The expense of fresh local produce deters me from purchasing it as often } \\
\text { as I would like. }\end{array}$ & $\square$ & $\square$ & $\square$ & $\square$ & $\square$ \\
\hline I generally purchase whole foods, rather than processed foods. & $\square$ & $\square$ & $\square$ & $\square$ & $\square$ \\
\hline $\begin{array}{l}\text { I give preference to purchasing foods that come from within } 100 \text { miles of } \\
\text { my location. }\end{array}$ & $\square$ & $\square$ & $\square$ & $\square$ & $\square$ \\
\hline $\begin{array}{l}\text { I give preference to eating foods that are in season. For example, tomatoes } \\
\text { in July-October. }\end{array}$ & $\square$ & $\square$ & $\square$ & $\square$ & $\square$ \\
\hline $\begin{array}{l}\text { I give preference to food purchase decisions that support the local } \\
\text { economy. }\end{array}$ & $\square$ & $\square$ & $\square$ & $\square$ & $\square$ \\
\hline I give preference to food purchase decisions that support local farmers. & $\square$ & $\square$ & $\square$ & $\square$ & $\square$ \\
\hline I believe consuming food produced locally is better for the environment. & $\square$ & $\square$ & $\square$ & $\square$ & $\square$ \\
\hline
\end{tabular}

18. Please rate the following in terms of importance for your food purchasing decisions:

\begin{tabular}{|l|l|l|l|l|l|}
\hline & $\begin{array}{l}\text { Not a } \\
\text { Priority }\end{array}$ & $\begin{array}{l}\text { Low } \\
\text { Priority }\end{array}$ & Neutral & $\begin{array}{l}\text { Moderate } \\
\text { Priority }\end{array}$ & $\begin{array}{l}\text { High } \\
\text { Priority }\end{array}$ \\
\hline Chemical Free & & & & & \\
\hline Convenience & & & & & \\
\hline Freshness/Quality & & & & & \\
\hline Locally produced & & & & & \\
\hline Nutrition & & & & & \\
\hline Price & & & & & \\
\hline
\end{tabular}




\section{Bloomington Community Farmers' Market Survey}

18. Please indicate your involvement in the following activities (one selection per line):

\begin{tabular}{|l|l|l|l|}
\hline Activities & Yes & Used to & Never \\
\hline Food preservation (i.e. freezing, canning, etc.) & & & \\
\hline Composting & & & \\
\hline Recycling & & & \\
\hline Vegetable gardening: at home & & & \\
\hline Vegetable gardening: in a community garden plot & & & \\
\hline Eating vegetarian/vegan & & & \\
\hline Support or belong to an environmental organization(s) & & & \\
\hline Reading about food nutrition & & & \\
\hline Reading nutrition labels on food packages & & & \\
\hline
\end{tabular}

\section{Section 3: Demographics}

19. How do you usually get to the grocery store?

$\square$ Personal vehicle

$\square$ Bike

$\square$ Walking

$\square$ Bus

$\square$ Shared Carpool

$\square$ Other:

20. How difficult is it for you to get to the store to buy groceries?

$\square$ Very difficult

$\square$ Difficult

$\square$ Easy

$\square$ Very Easy

20a. If very difficult or difficult, why?

20b. If very easy or easy, why?

21. How many people, including yourself, live in your household full time?

Of these, how many are below the age of 18 ?

22. What is your gender?

$\square$ Female

$\square$ Male

$\square$ other:

23. What year were you born? 


\section{Bloomington Community Farmers' Market Survey}

24. What is your race/ethnicity?

$\square$ African American or Black

$\square$ American Indiana and Alaska

Native

$\square$ Asian

$\square$ Native Hawaiian or Other Pacific Islander

$\square$ White

$\square$ Hispanic

$\square$ Other:

25. How often do you participate in organized religious services/programs?
$\square$ weekly
$\square$ several times a year
$\square$ 2-3 times a month
$\square$ yearly
$\square$ monthly
$\square$ never

26. What is the last grade/degree you completed in school?
$\square 1^{\text {st }} 4^{\text {th }}$ grade
$\square$ Some college no degree
$\square 5^{\text {th }} 6^{\text {th }}$ grade
$\square$ Associate's degree
$\square 7^{\text {th- }} 8^{\text {th }}$ grade
$\square$ Bachelor's degree
$\square 9^{\text {th }}$ grade
$\square$ Master's degree
$\square 10^{\text {th }}$ grade
$\square$ Professional degree
$\square 11^{\text {th }}$ grade
$\square$ Doctoral degree
$\square \mathrm{HS} / \mathrm{GED}$

27. What was your gross household income last year?

$\square \$ 0-\$ 15,000$

$\square \$ 90,000-\$ 120,000$

$\square \$ 15,000-\$ 30,000$

$\square \$ 120,000-\$ 150,000$

$\square \$ 30,000-\$ 45,000$

$\square \$ 150,000-\$ 180,000$

$\square \$ 45,000-\$ 60,000$

$\square \$ 180,000-\$ 250,000$

$\$ 60,000-\$ 75,000$

$\square \$ 250,000+$

$\$ 75,000-\$ 90,000$

28. What cross streets are closest to your house (closest intersection)?
a)
b) 